\title{
Combination of Cysteamine and Lipoic Acid Improves the Post-Thawed Bull Sperm Parameters
}

\author{
Şükrü GÜNGÖR ${ }^{1}$, Adil AKSOY ${ }^{2}$, Deniz YENİ ${ }^{3}$, Fatih AVDATEK ${ }^{3}$, Caner ÖZTÜRK ${ }^{4}$, Mehmet \\ BOZKURT ATAMAN ${ }^{5}$, Kenan COYAN ${ }^{6}$, Mustafa Numan BUCAK ${ }^{5}$, Nuri BAŞPINAR ${ }^{7}$, Pınar \\ PEKER AKALIN ${ }^{8}$
}

\author{
${ }^{1}$ Mehmet Akif Ersoy University,Faculty of Veterinary Medicine,Department of Reproduction and Artificial Insemination, Burdur/TURKEY \\ ${ }^{2}$ Republic of Turkey, Prime Ministry, Ankara/TURKEY \\ ${ }^{3}$ Afyon Kocatepe University, Faculty of Veterinary Medicine, Department of Reproduction and Artificial Insemination, Afyon/TURKEY \\ 4 Aksaray University, Faculty of Veterinary Medicine, Department of Reproduction and Artificial Insemination, Aksaray/TURKEY \\ 5 Selcuk. University, Faculty of Veterinary Medicine, Department of Reproduction and Artificial Insemination, Konya/TURKEY \\ ${ }^{6}$ Pamukeale University, Faculty of Medicine, Department of Histology and Embryology, Denizli/TURKEY \\ ${ }^{7}$ Selcuk University, Faculty of Veterinary Medicine, Department of Biochemistry, Konya/TURKEY \\ ${ }^{8}$ Mustafa Kemal University, Faculty of Veterinary Medicine, Department of Biochemistry, Hatay/TURKEY
}

Corresponding author e-mail: sukrugungor@mehmetakif.edu.tr

\section{ABSTRACT}

The present study was conducted to examine the protective roles of cysteamine, trehalose, alpha-lipoic acid and combinations of these antioxidants on post-thawed bull sperm and oxidative stress parameters. Five healthy Holstein bull (3-4 years old) were used. Eight ejaculates for each bull were collected and pooled. Pooled ejaculate, splitted into seven equal aliquots and diluted at $37^{\circ} \mathrm{C}$ with base extenders containing cysteamine $2 \mathrm{mM}$, trehalose $50 \mathrm{mM}$, alpha-lipoic acid (ALA) $1 \mathrm{mM}$, cysteamine $2 \mathrm{mM}+$ trehalose $50 \mathrm{mM}$, ALA $1 \mathrm{mM}+$ trehalose $50 \mathrm{mM}$, cysteamine $2 \mathrm{mM}+$ ALA $1 \mathrm{mM}$ and no antioxidant (control), was cooled to $5{ }^{\circ} \mathrm{C}$ and then frozen. Frozen straws were thawed in a water bath for evaluation. The combination of cysteamine $2 \mathrm{mM}$ and ALA $1 \mathrm{mM}$ of the semen extender improved the percentages of post-thawed subjective motility $(68 \pm 2.7 \%)$, and progressive motility $(42.9 \pm 4.7 \%)$, compared with the controls $(61 \pm 4.2 \%$ and $37.5 \pm 8 \%$, respectively, non- significantly, P>0.05). The supplementation of the semen extender with combination of cysteamine $2 \mathrm{mM}$ and ALA $1 \mathrm{mM}$ produced a higher acrosome integrity and mitochondrial activity $(52.02 \pm 6.4 \%$ and $32 \pm 4.1 \%$, respectively), compared with the controls $(30.5 \pm 1.7$ and $14.02 \pm 3.5 \%$ respectively, $\mathrm{P}<0.05)$. Combination of cysteamine and ALA antioxidants in semen extenders provided the benefit in terms of sperm motilities, acrosome integrity and mitochondrial activity on frozen-thawed bull sperm

Key Words: Alpha Lipoic Acid, Bull Sperm, Cysteamine, Fluorescent Staining, Trehalose

\section{Sisteamin ve Alfa Lipoik Asit Kombinasyonunun Dondurulmuş-Çözdürülmüş Boğa Spermas1 Parametreleri Üzerine Etkisi ÖZ}

Sunulan çalışmada sisteamin, trehaloz, alfa-lipoik asit ve bu antioksidan kombinasyonlarının, çözüm sonu boğa spermasında spermatolojik ve oksidatif stres parametreleri üzerine koruyucu etkinliklerinin belirlenmesi amaçlandı. Beş adet sağlıklı holştayn (3-4 yaşlarında) 1rkı boğa kullanıldı. Çalışmada kullanılan her boğadan 8 ejakülat alındı. Alınan ejakülatlar miks yapılarak 37 ${ }^{\circ} \mathrm{C}$ 'de 7 eşit hacme bölündükten sonra, sisteamin $2 \mathrm{mM}$, trehaloz $50 \mathrm{mM}$, alfa-lipoik asit (ALA) $1 \mathrm{mM}$, sisteamin $2 \mathrm{mM}+$ trehaloz $50 \mathrm{mM}$, ALA $1 \mathrm{mM}+$ trehaloz $50 \mathrm{mM}$, sisteamin $2 \mathrm{mM}+$ ALA $1 \mathrm{mM}$ ve antioksidan içermeyen (kontrol) temel sulandırıcı ile sulandırılarak $5^{\circ} \mathrm{C}$ 'de soğutulmasının ardından donduruldu. Dondurulan payetler su banyosunda çözdürülerek değerlendirildi. Sisteamin $2 \mathrm{mM}+$ ALA $1 \mathrm{mM}$ kombinasyonunu içeren sperma sulandırıcısının çözüm sonu subjektif $(\% 68 \pm$ 2.7) ve progresif motilite (\% $42.9 \pm 4.7)$ oranları üzerine kontrol gruplarına kıyasla (\% $61 \pm 4.2$ ve $\% 37.5 \pm 8)$ olumlu etkinliği gözlenirken istatiksel olarak fark önemsiz bulundu ( $>$ > 0.05). Sisteamin $2 \mathrm{mM}+$ ALA $1 \mathrm{mM}$ kombinasyonu içeren sperma sulandırıcı grubu akrozom bütünlüğ̈ ve mitokondriyal aktivite oranları (\% $52.02 \pm 6.4$ ve \% $32 \pm 4.1)$ kontrol gruplarına (\% $30.5 \pm 1.7$ ve \% $14.02 \pm 3.5)$ göre istatistiksel olarak daha yüksek bulundu $(\mathrm{P}<0.05)$. Dondurulmuş çözdürülmüş boğa sperma sulandırıcılarına eklenen sisteamin ve ALA kombinasyonu spermatozoon motilitesine, akrozom bütünlügüne ve mitokondriyal aktivite bütünlüğ̈̈ne katk1 sağladı.

Anahtar Kelimeler: Alfa Lipoik Asit, Boğa Sperması, Sisteamin, Floresan Boyama, Trehaloz

To cite this article:Güngör Ş, Aksoy A,Yeni D, Avdatek F, Öztürk C, Ataman MB, Coyan K, Bucak MN, Başpinar N, Akalin PP . Combination of cysteamine and lipoic acid improves the post-thawed bull sperm parameters. Kocatepe Vet J.2016; 9(2):88-96. 


\section{INTRODUCTION}

Bull sperm cryopresarvation has been widely used as an important instrument of the livestock industry, particularly in a relation to the dipersion of genetic material and the banking of genomic growths to retain superior transgenic lines (Bucak et al., 2010). In the bovine dairy industry, artificial insemination (AI) is the method used worldwide to manage reproduction (Vishwanath, 2000). It has been predicted that $95 \%$ of the total artificial insemination doses are frozen (Thibier and Wagner, 2002).

The quality of frozen semen has an impact on conception rates. Frozen semen quality is bound up with the semen extender (El-Sheshtawy et al., 2015). Mammalian sperm cells contains highly specific lipid composition, namely high content of polyunsaturated fatty acids. This unconventional structure of sperm membrane is responsible for its flexibility and the functional skills. However, spermatozoa's lipids are the main substrates for peroxidation, that may threat sperm survival. This pathological peroxidation of lipids makes sperm membranes unstable during oxidative stress (Sanocka and Kurpisz 2004). Cryopreservation provokes damage to spermatozoa that may end up with the loss of motility, viability, plasma membrane integrity, fertilizing capacity and causation of sperm apoptosis (Aitken et al 1998; Vishwanath 2000; Medeiros et al., 2002). Oxidative stress can also induce DNA fragmentation in the spermatozoa (Aitken et al. 2009) and artificially created oxidative stress can induce DNA damage (Aitken et al 1998). Sperm extender composition could induce reduction of the oxygen levels that may result formation of reactive oxygen species (ROS) can lead to oxidative stress. Balaban et al (2005) were stressed that ROS also formed during normal oxidative metabolism in the cell due to an imbalance of intracellular redox potential. Uncontrolled ROS levels could stir up sperm cell substrates by lipid peroxidation, protein modification, and DNA damage resulting in impaired cell function and subsequently can affect sperm survival. But also, an adequate physiological level of ROS is required for fertilization (De Lamirande et al 1997) and apoptosis (Merton et al. 2013).

Sperm cryopreservation techniques cause cold shock, ice crystal formation, osmotic changes, oxidative stress that may end up with cell damage (Watson, 1995; Bailey et al 2000).

Cysteamine induces the uptake of cysteine by cells thereby enhancing the GSH synthesis. As a result of this cycle, cysteamine has vital role in the defense mechanism against ROS (Merton et al., 2013). Bovine, ovine, pig, hamster and buffalo embryo development studies emphasized that cysteamine decreased hydrogen peroxide levels (de Matos et al., 2002; Grupen et al., 1995, Kito and Bavister, 1997,
Gasparrini et al. 2003). Bucak et al., (2009) also reported that cysteamine enhanced motility and elevated the antioxidant capacity of post-thawed ram sperm.

Osmotic balance of sperm diluents is critical to reduce intracellular ice crystal formation. Sperm extenders mostly include sugars like sucrose, raffinose and trehalose for cryoprotection (Garde et al 2008).

Trehalose is a non-penetrating disaccharide, which has a protective role on cells both by increasing the tonicity of the extender and by stabilizing the plasma membrane. Trehalose binds to membrane phospholipid bilayer due to specific interactions with head groups of membrane phospholipids leading to more stable membrane against freeze-induced damage (Crowe et al 1987, Aboagla and Terada, 2003). This positive effect of trehalose was mentioned in many studies established in ram (Bucak and Tekin 2007; Tonieto et al 2010), goat (Khalili et al 2009; Aboagla and Terada, 2003) and bull (Woelders 1997; El-Sheshtawy et al 2015).

Alpha-Lipoic acid (ALA; 1,2-dithiolane-3-pentanoic acid), which plays an important role in mitochondrial dehydrogenase reactions, was found in all types of prokaryotic and eukaryotic cells and is a naturally occurring nutraceutical, whose therapeutic act has been contributed to its antioxidant activity and its ability to fix oxidative injury (Biewenga et al 1997). Alpha-Lipoic acid is characterized by its high reactivity towards free radicals and its ability to increase tissue levels of reduced glutathione and to reduce formation of lipid peroxides (LPOs), consequently restoring ability of normal antioxidant enzymes profile (El-Beshbishy et al 2011). AlphaLipoic acid had a protective role against lipopolysaccharide-induced oxidative stress in adult rat Sertoli cells, in vitro (Aly et al 2009). Also, pretreatment with ALA protected the structural integrity of erythrocyte cell membrane components that were exposed to oxidative damage by gamma radiation (Desouky et al 2011).

The aim of this study was to determine the effects of cysteamine, trehalose, ALA and combinations of these antioxidants on sperm motility, sperm motion parameters VAP (average path velocity, $1 \mu \mathrm{m} \mathrm{s}^{-1}$ ), VSL (straight linear velocity, $1 \mu \mathrm{m} \mathrm{s}^{-1}$ ), VCL (curvilinear velocity, $1 \mu \mathrm{m} \mathrm{s}^{-1}$ ), ALH (amplitude of lateral head displacement, $1 \mu \mathrm{m}$ ) and LIN (linearity index (LIN = (VSL/VCL) $\times 100)$, viability, acrosome integrity, mitochondrial activity, lipid peroxidation (LPO) and antioxidant potential (AOP) levels in bull semen.

\section{MATERIALS and METHODS}

\section{Animals and semen collection}

Five healthy Holstein bulls (3-4 years of age) housed at a private dairy farm in Konya and maintained with 
standard feeding and management practices were used. Ejacultes were collected twice a week with the aid of an artificial vagina. A total number of 40 ejaculates (8 ejaculates from each bull) were collected. Sperm motility was estimated subjectively using phase-contrast microscopy with a warm stage maintained at $37^{\circ} \mathrm{C}$ at $400 \times$ magnification. Only ejaculates having $\geq 80 \%$ sperm motility and concentrations higher than 800 x $10^{6}$ spermatozoa $/ \mathrm{ml}$ were cryopreserved. After collection, the ejaculates were immersed in a warm water bath at $34^{\circ} \mathrm{C}$. The ejaculates were mixed in a pool for balancing the sperm contribution of each bull.

\section{Semen processing}

The volume of ejaculates was measured in a conical tube graduated at $0.1 \mathrm{ml}$ intervals and sperm concentration was determined by means of an Accucell photometer (IMV, L'Aigle, France). Sperm motility was estimated using phase-contrast microscopy $(200 \times)$. A Tris-based extender (Tris $254 \mathrm{mM}$, citric acid $78 \mathrm{mM}$, fructose $70 \mathrm{mM}$, egg yolk 15\% (v/v), glycerol $6 \%(\mathrm{v} / \mathrm{v}), \mathrm{pH} 6.8)$ was used as the base extender (cryopreservation diluent). Each ejaculate was split into seven equal experimental groups and diluted to a final concentration of $60 \times 10^{6} / \mathrm{ml}$ spermatozoa with the base extender containing cysteamine $2 \mathrm{mM}$, trehalose $50 \mathrm{mM}$, alpha-lipoic acid (ALA) $1 \mathrm{mM}$, cysteamine $2 \mathrm{mM}+$ trehalose $50 \mathrm{mM}$, ALA $1 \mathrm{mM}+$ trehalose $50 \mathrm{mM}$, cysteamine $2 \mathrm{mM}+$ ALA $1 \mathrm{mM}$ and no antioxidant (control), was cooled to $5{ }^{\circ} \mathrm{C}$ and then frozen. Diluted semen samples were loaded into $0.25-\mathrm{ml}$ French straws and cooled down to $4{ }^{\circ} \mathrm{C}$ in $2 \mathrm{~h}$, frozen at a programmed rate of $-3^{\circ} \mathrm{C} / \mathrm{min}$ from +4 to $-10^{\circ} \mathrm{C} ;-40{ }^{\circ} \mathrm{C} / \mathrm{min}$ from -10 to $-100^{\circ} \mathrm{C}$; $-20^{\circ} \mathrm{C} / \mathrm{min}$ from -100 to $-140{ }^{\circ} \mathrm{C}$ in a digital freezing machine (Digitcool 5300 ZB 250, IMV, France). Thereafter, the straws were plunged into liquid nitrogen. The study was replicated nine times. At least after $24 \mathrm{~h}$, frozen straws were thawed in a $37^{\circ} \mathrm{C}$ water bath for $20 \mathrm{~s}$ immediately before use.

\section{Evaluation of microscopic sperm parameters}

To analyse sperm motility and various kinematic parameters, Sperm Class Analyzer $\left(\mathrm{SCA}^{\circledR}\right)$ CASA system (Microptic S.L., Barcelona, Spain) was used. A $5 \mu \mathrm{l}$ sample of diluted semen was put onto a prewarmed slide covered with a coverslip and sperm motility characteristics were determined with a $10^{9}$ objective at $37{ }^{\circ} \mathrm{C}$. The following motility values were recorded: progressive motility (\%), VAP, VSL, VCL, ALH and LIN. For each evaluation, seven microscopic fields, each including at least 250 cells, were analysed.

\section{Assessment of sperm acrosome integrity}

Sperm acrosome status was assessed using fluorescein isothiocyanate conjugated to Arachis hypogaea (peanut) (L7381 FITC-PNA, SigmaAldrich Co., St. Louis, MO, USA) and by PI staining as described by Nagy et al. (2003) with modifications. $120 \mu \mathrm{g}$ of FITC-PNA was added to 1 $\mathrm{ml}$ of PBS for the preparation of the staining solution, and then divided into equal aliquots (100 $\mu \mathrm{l})$ after being filtered and stored at $-20{ }^{\circ} \mathrm{C}$. Thawed straws were diluted 1:3 with Tris stock solution without glycerol and egg yolk, and then $60 \mu \mathrm{l}$ of the diluted semen was mixed with $10 \mu$ of FITC-PNA and $2.5 \mu \mathrm{l}$ of PI. The sample was gently mixed, incubated at $37^{\circ} \mathrm{C}$ in the dark for $20 \mathrm{~min}$ and added $10 \mu \mathrm{l}$ of Hancock's solution (Schafer and Holzmann, 2000) for semen fixation. A wet mount was made using a $2.5 \mu \mathrm{l}$ drop of the sample placed directly onto a microscope slide and covered with a cover slip. At least 200 sperm cells per sample were examined at 400x magnification under a fluorescence microscope (Leica DM 3000 Microsystems GmbH, Ernst-LeitzStraße, Wetzlar, Germany; excitation at 450-490 nm, emission at $520 \mathrm{~nm}$ ) to assess sperm acrosome integrity. Spermatozoa displaying bright green or patchy green fluorescence were considered as acrosome nonintact or damaged, whereas cells which did not display green fluorescence in the acrosome cap were regarded as acrosome intact.

\section{Assessment of sperm mitochondrial activity}

Sperm mitochondrial activity was assessed with a staining protocol modified from Garner et al. (1997). A stock solution of 5,50, 6,60-tetrachloro-1,10, 3,30 tetraethyl-benzimidazolylcarbocyanine iodide (1.53 $\mathrm{mM}$ ) (T3168 JC-1, Invitrogen) was prepared in DMSO, divided into equal aliquots $(100 \mu \mathrm{l})$ after being filtered and then stored at $-20{ }^{\circ} \mathrm{C}$. Thawed straws were diluted 1:3 with Tris stock solution without glycerol and egg yolk, and then $300 \mu \mathrm{l}$ of the diluted semen was mixed with $2.5 \mu \mathrm{l} \mathrm{JC}-1$ and $2.5 \mu \mathrm{l}$ PI. The sample was gently mixed, incubated at $37^{\circ} \mathrm{C}$ in the dark for $20 \mathrm{~min}$ and was added $10 \mu \mathrm{l}$ of Hancock's solution (Schafer and Holzmann, 2000) for semen fixation. A wet mount was made using a $2.5 \mu \mathrm{l}$ drop of the sample placed directly onto a microscope slide and covered by a cover slip. At least 200 sperm cells per sample were examined at $400 \mathrm{x}$ magnification under a fluorescence microscope (Leica DM 3000; excitation at 450-490 $\mathrm{nm}$, emission at $520 \mathrm{~nm}$ ) to assess mitochondrial activity. A high level of yellow/orange fluorescence associated with the sperm midpiece (where the mitochondria are located) indicated high mitochondrial activity. Mitochondria with low activity stained green.

\section{Oxidative stress parameters}

Briefly, thawed semen samples were centrifuged at $800 \mathrm{~g}$ for $20 \mathrm{~min}$ at $4{ }^{\circ} \mathrm{C}$ to separate the cells from the diluted seminal plasma, and then spermatozoa were washed twice with PBS at $800 \mathrm{~g}$ for $20 \mathrm{~min}$. After centrifugation, the supernatant was discarded, and the pellet was completed to $500 \mu \mathrm{l}$ with PBS. Subsequently, the sperm suspension was transferred into a $2 \mathrm{ml}$ beaker filled with ice water and sonicated 
with a probe (Bandelin Sonopuls, Bandelin ElectronicHeinrichstraBe, D-12207, Gerate-Typ:UW 2070,Pro-Nr. 51900037369.004, Berlin, Germany) for $10 \mathrm{~s}$ on ice repeated six times at intervals of $30 \mathrm{~s}$ to separate the sperm head and tail. For LPO analysis, $10 \mu \mathrm{l}$ of $0.5 \mathrm{mM}$ BHT (butylhydroxytoluene) was added into $120 \mu \mathrm{l}$ of the homogenate samples and stored at $-86{ }^{\circ} \mathrm{C}$ until analysis. The remaining homogenate was centrifuged at $8000 \mathrm{~g}$ for $15 \mathrm{~min}$ at $+4{ }^{\circ} \mathrm{C}$, and the supernatant was collected and stored at $-86{ }^{\circ} \mathrm{C}$ for AOP analysis.

\section{Determination of lipid peroxidation level}

Lipid peroxidation level was determined using commercial kits of LPO 586 ${ }^{\mathrm{TM}}$ Oxis Research (OxisResearch ${ }^{\mathrm{TM}}$, Bioxytech, CA, 92202, USA) by spectrophotometry (UV 2100 UV-VIS Recording Spectrophotometer Shimadzu, Japan). The assay is based on the reaction of a chromogenic reagent, $\mathrm{N}$ methyl-2- phenylindole with MDA and 4hydroxyalkenals (LPO) at $45{ }^{\circ} \mathrm{C}$. One molecule of either MDA or 4-hydroxyalkenal reacts with two molecules of N-methyl-2-phenylindole in acetonitrile, to yield a stable chromophore with maximal absorbance at $586 \mathrm{~nm}$. The results are expressed as $\mu \mathrm{mol}$ for $10^{9}$ cells $\mathrm{ml}^{-1}$.

\section{Determination of Total Antioxidant Potential}

Antioxidant potential was determined with an AOP490TM Oxis Research kit (OxisResearch ${ }^{\mathrm{TM}}$, Bioxytech, CA, 92202, USA) by spectrophotometry. The assay was based on the reduction ofCu++ to $\mathrm{Cu}+$ by the combined action of all the antioxidants present in the sample. A chromogenic reagent, bathocuproine (2,9-dimethyl-4,7-diphenyl-1,10phenanthroline), selectively forms a 2:1 complex with $\mathrm{Cu}+$, which has a maximum absorbance at 490 nm. A standard of known uric acid (a watersoluble antioxidant) concentration is used to create a calibration curve. The results are expressed as mmol for $10^{9}$ cells $\mathrm{ml}^{-1}$.

\section{Statistical analysis}

Results were expressed as mean \pm SEM. Sperm motility, motion characteristics, abnormality and oxidative stress parameters were analysed by analysis of variance (ANOVA), followed by Tukey's post hoc test to determine significant differences between the groups. Differences with values of $\mathrm{p}<0.05$ were considered to be statistically significant. Statistical analyses were performed by using the SPSS 13 package program.

\section{RESULTS}

The combination of cysteamine $2 \mathrm{mM}$ and alphaLipoic acid $1 \mathrm{mM}$ increased the percentages of postthawed subjective motility $(68 \pm 2.7 \%)$, and progressive motility $(42.9 \pm 4.7 \%)$, compared with the controls $(61 \pm 4.2$ and $37.5 \pm 8 \%$, respectively, with no significant differences $\mathrm{p}>0.05$ ) (Table 1). Significant differences were observed between the trehalose 50
$\mathrm{mM}$ and control groups for VSL (67.08 \pm 14.2 , $57.3 \pm 6.8 \mu \mathrm{m} / \mathrm{s})$ and LIN (58.16 $\pm 6.8,49.38 \pm 3.6 \%)$ levels respectively, $(\mathrm{p}<0.05)$. Combination of cysteamine $2 \mathrm{mM}$ and alpha-Lipoic acid $1 \mathrm{mM}$ provided a higher VCL $(122.76 \pm 7.9 \mu \mathrm{m} / \mathrm{s})$ in comparison to the control group (105.24 \pm 10.9 $\mu \mathrm{m} / \mathrm{s}, \mathrm{p}<0.05$ ) (Table 2). The combination of cysteamine $2 \mathrm{mM}$ and alpha-lipoic acid $1 \mathrm{mM}$ increased acrosome integrity and mitochondrial activity (52.02 \pm 6.04 and $32 \pm 4.1 \%$, respectively), compared with those of the control group (30.5 \pm 1.7 and $14.02 \pm 3.5 \%, \mathrm{p}<0.05$ ) (Table 3). Regarding biochemical assays, no significant difference was observed in LPO and AOP levels among groups ( $p$ $>0.05$ ) (Table 4).

\section{DISCUSSION}

Spermatozoa cryodamage caused by the cryopreservation procedure results in impaired fertility and decrease survival of spermatozoa in female reproductive system (Singh et al., 2012). Cryoinjury leads to ultrastructural damage on the plasma and acrosomal membranes by triggering the production of ROS (Salamon and Maxwell 1995). The antioxidants scavenge free radicals and improve sperm parameters (Bansal and Bilaspuri 2011; Gharagozloo and Aitken 2011). This study investigated the protective effects of the antioxidants cysteamine, trehalose, alpha-lipoic acid and combinations of these antioxidants against cryoinjury with the evaluation of sperm and oxidative stress parameters following freeze-thawing of bull semen.

Trehalose acts like non-permeating cryoprotectant which causes dehydration of spermatozoa due to the osmotically driven flow of water. Due to this mild dehydration, spermatozoa have less intracellular water which results in reduced intracellular ice crystal formation consequenlty preventing spermatozoa from cryodamage (Chhillar et al 2012). In the present study, $50 \mathrm{mM}$ trehalose did not show a significant $(p>0.05)$ increase in post-thaw sperm subjective and CASA progressive motilities, but it ameliorated mitochondrial activity and acrosome integrity compared to control group. These findings are similar with Cirit et al. (2013), but opposite from (Bucak and Tekin, 2007; Uysal et al, 2007; GutierrezPerez et al., 2009; Hu et al., 2010; Reddy et al., 2010; Singh et al., 2012, El-Sheshtway et al., 2015). The differences in the current study may be attributed to the different extender types, doses and cooling and freezing protocols.

Combination of Trehalose $50 \mathrm{mM}$ and cysteamine 2 $\mathrm{mM}$ gave better LIN values of sperm characteristics compared to the controls. These findings were similar with Bhattacharyya et al. (2006). The studies showed that cysteamine conferred better cryoprotection on frozen ram sperm (Bucak and Tekin, 2007), and higher embryo development rates 
when added into the maturation medium of goat oocytes (Rodriguez-Gonzalez et al., 2003). In this study, while cysteamine alone and combination with alpha-lipoic acid resulted in higher rates of motility, acrosome integrity and mitochondrial activity, it did not cause a significant difference on oxidative stress parameters. Beside this, cystamine gave lower LPO and higher AOP levels compared the control. These findings are in agreement with the results of our previous study that was performed in ram semen (Bucak and Tekin, 2007; Bucak et al., 2009).

Alpha-lipoic acid is readily distributed and accumulates in several tissues where it is rapidly converted to its more potent antioxidant form dihydrolipoic acid (Packer et al., 1997). Because of its small size and high lipophilicity, it crosses biological membranes easily and quenches free radicals in both lipid and aqueous environments (Suzuki et al., 1991). Alpha lipoic acid also provided a cryoprotective effect on boar semen during the process of freezingthawing (Shen et al. 2015), and during liquid storage (Pîndaru and Groza, 2015). Also Bucak et al., (2009) reported that, cysteamine enhanced motility and elevated the antioxidant capacity of post-thawed ram sperm. Cysteamine and ALA combination may improve antioxidant defence system via glutathione (GSH) synthesis. Cysteamine induces the uptake of cysteine by cells thereby enhancing the GSH synthesis (Merton et al. 2013). Glutathione is the major cellular sulfhydryl compound that serves as both a nucleophile and an effective reductant by interacting with numerous electrophilic and oxidizing compounds. Aly et al. (2006) reported that, lipoic The present study showed that ALA $1 \mathrm{mM}$ improved the post-thaw subjective motility compared the control. It also gave better results with the combination of cysteamine on sperm motility parameters, sperm motion characteristics and florescant dye results. These findings are in good agreement with researchers; lipoic acid was reported to improve the semen quality and reduced the oxidative stress and DNA damage induced by cyclophosphamide in rats (Selvakumar et al., 2006).

acid increased GSH levels on lipopolysaccharideinduced oxidative stress in adult rat Sertoli cells.

In the present study, it is concluded that combination of cysteamine and alpha-lipoic acid provided a protective effect, by improving the spermatological parameters. The extenders including cysteamine and alpha-lipoic acid combination may be recommended to improve bull semen cryopreservation.

Table 1: Mean ( \pm SEM) sperm motility in frozenthawed bull semen.

Tablo 1: Dondurulmuş-Çözdürülmüş Boğa Spermasında Ortalama (£SEM) Motilite Değerleri.

\begin{tabular}{lcc}
\hline Groups & Subjectivemotility $\%)$ & Progressivemotility $\%$ \\
Control & $61 \pm 4.2^{\mathrm{abc}}$ & $37.5 \pm 8^{\mathrm{a}}$ \\
Cysteamine $2 \mathrm{mM}$ & $64 \pm 5.4^{\mathrm{bc}}$ & $39.5 \pm 5.3^{\mathrm{a}}$ \\
LipoicAcid $1 \mathrm{mM}$ & $66 \pm 4.1^{\mathrm{c}}$ & $35.4^{\mathrm{a}} \pm 5.4^{\mathrm{a}}$ \\
Trehalose $50 \mathrm{mM}$ & $58 \pm 5.7^{\mathrm{ab}}$ & $42.4^{\mathrm{a}} \pm 7.7^{\mathrm{a}}$ \\
Cysteamine $2 \mathrm{mM}+$ Trehalose & $54 \pm 6.5^{\mathrm{a}}$ & $38.7^{\mathrm{a}} \pm 9.5^{\mathrm{a}}$ \\
$50 \mathrm{mM}$ & & $40.5 \pm 9^{\mathrm{a}}$ \\
LipoicAcid1mM + Trehalose & $64 \pm 6.5^{\mathrm{bc}}$ & $42.9^{\mathrm{a}} \pm 4.7^{\mathrm{a}}$ \\
$50 \mathrm{mM}$ & & \\
Cysteamine $2 \mathrm{mM}+$ & $68 \pm 2.7^{\mathrm{c}}$ & $\mathrm{NS}$ \\
LipoicAcid $1 \mathrm{mM}$ & $*$ & \\
\hline $\mathrm{P}$ & $*$ & \\
\hline
\end{tabular}

NS: Not significant a, b ,c: Different superscripts within the same column demonstrate significant differences.

$(* \mathrm{p}<0.05)$. 
Table 2: Mean ( \pm SEM) CASA parameters in frozen-thawed bull semen.

Tablo 2: Dondurulmuş-Çözdürülmüş Boğa Spermasında Ortalama (£SEM) CASA Parametreler

\begin{tabular}{|c|c|c|c|c|c|}
\hline Groups & VAP & VSL & VCL & ALH & LIN \\
\hline Control & $77.36 \pm 6.4^{\mathrm{a}}$ & $57.3 \pm 6.8^{\mathrm{ab}}$ & $115.78 \pm 7.1^{\mathrm{ab}}$ & $4.32 \pm 0.2^{\mathrm{bc}}$ & $49.38 \pm 3.6^{a}$ \\
\hline Cysteamine $2 \mathrm{mM}$ & $81.42 \pm 4.9^{\mathrm{a}}$ & $61.48 \pm 4.2^{\mathrm{ab}}$ & $123.22 \pm 6^{c}$ & $4.44 \pm 0.2^{c}$ & $49.94 \pm 3.6^{\mathrm{a}}$ \\
\hline LipoicAcid1mM & $78.32 \pm 5^{a}$ & $57.62 \pm 6.3^{\mathrm{ab}}$ & $119.16 \pm 5.3^{c}$ & $4.56 \pm 0.2^{c}$ & $48.36 \pm 4.8^{\mathrm{a}}$ \\
\hline Trehalose $50 \mathrm{mM}$ & $77 \pm 7.1^{\mathrm{a}}$ & $67.08 \pm 14.2^{\mathrm{b}}$ & $115.02 \pm 16^{\mathrm{ab}}$ & $3.94 \pm 0.5^{\mathrm{ab}}$ & $58.16 \pm 6.8^{\mathrm{b}}$ \\
\hline Cysteamine $2 \mathrm{mM}+$ & $73.32 \pm 7.3^{\mathrm{a}}$ & $58.38 \pm 3.9^{\mathrm{ab}}$ & $105.24 \pm 10.9^{a}$ & $3.74 \pm 0.3^{\mathrm{a}}$ & $55.64 \pm 2.4^{\mathrm{b}}$ \\
\hline \multicolumn{6}{|l|}{ Trehalose $50 \mathrm{mM}$} \\
\hline $\begin{array}{l}\text { LipoicAcid1mM + } \\
\text { Trehalose } 50 \mathrm{mM}\end{array}$ & \multicolumn{4}{|c|}{ Trehalose 50mM } & $49.46 \pm 1.7^{a}$ \\
\hline \multicolumn{6}{|l|}{ LipoicAcid1mM } \\
\hline $\mathrm{p}$ & NS & * & * & * & * \\
\hline
\end{tabular}

NS: Not significant a, b ,c: Different superscripts within the same column demonstrate significant differences. $\left({ }^{*} \mathrm{p}<0.05\right)$.

Table 3: Mean ( \pm SEM) Flourescent staining in frozen-thawed bull semen.

Tablo 3: Dondurulmuş-Çözdürülmüş Boğa Spermasında Ortalama ( \pm SEM) Floresan Boyama Değerleri.

\begin{tabular}{lcc}
\hline Groups & Acrosome Integrity $(\%)$ & High Mitochondrial Activity $(\%)$ \\
Control & $30.5 \pm 1.7^{\mathrm{a}}$ & $14.02 \pm 3.5^{\mathrm{a}}$ \\
Cysteamine $2 \mathrm{mM}$ & $34.58 \pm 5.7^{\mathrm{ab}}$ & $26.72 \pm 5.5^{\mathrm{ab}}$ \\
LipoicAcid $1 \mathrm{mM}$ & $40.7 \pm 12.1^{\mathrm{abc}}$ & $20.78 \pm 6.3^{\mathrm{ab}}$ \\
Trehalose $50 \mathrm{mM}$ & $47.25 \pm 10^{\mathrm{cd}}$ & $32.42 \pm 2.9^{\mathrm{c}}$ \\
Cysteamine $2 \mathrm{mM}+$ Trehalose & $44.14 \pm 5.6^{\mathrm{bcd}}$ & $24.68 \pm 2.9^{\mathrm{bc}}$ \\
$50 \mathrm{mM}$ & & $32 \pm 4.1^{\mathrm{c}}$ \\
LipoicAcid $1 \mathrm{mM}+$ Trehalose & $40.34 \pm 9.03^{\mathrm{abc}}$ & \\
$50 \mathrm{mM}$ & & $*$ \\
Cysteamine $2 \mathrm{mM}+$ & $52.02 \pm 6.4^{\mathrm{d}}$ & \\
LipoicAcid $1 \mathrm{mM}$ & $*$ & \\
\hline p & & \\
\hline
\end{tabular}

a, b ,c: Different superscripts within the same column demonstrate significant differences. $\left({ }^{*} \mathrm{p}<0.05\right)$. 
Table 4: Mean ( \pm SEM) LPO $\left(\mu \mathrm{Mx} 10^{9}\right)$ and AOP $\left(\mathrm{mMx} 10^{9}\right)$ levels in frozen-thawedbull semen.

Tablo 4: Dondurulmuş-çözdürülmüş boğa spermasında ortalama $\left( \pm\right.$ sem) lpo $\left(\mu \mathrm{mx} 10^{9}\right)$ ve aop $\left(\mathrm{mmx} 10^{9}\right)$ düzeyleri

\begin{tabular}{lcc}
\hline Groups & $\operatorname{LPO}\left(\mu \mathrm{Mx} 10^{9}\right)$ & AOP $\left(\mathrm{mMx} 10^{9}\right)$ \\
Control & $26.38 \pm 8.5^{\mathrm{a}}$ & $22.94 \pm 5.6^{\mathrm{a}}$ \\
Cysteamine $2 \mathrm{mM}$ & $24.1 \pm 11^{\mathrm{a}}$ & $26.74 \pm 12.2^{\mathrm{a}}$ \\
LipoicAcid1 $\mathrm{mM}$ & $31.64 \pm 27.8^{\mathrm{a}}$ & $23.3 \pm 5.7^{\mathrm{a}}$ \\
Trehalose $50 \mathrm{mM}$ & $24.14 \pm 7,8^{\mathrm{a}}$ & $23.34 \pm 12.3^{\mathrm{a}}$ \\
Cysteamine $2 \mathrm{mM}+$ Trehalose & $21.12 \pm 5.9^{\mathrm{a}}$ & $22.42 \pm 8.6^{\mathrm{a}}$ \\
$50 \mathrm{mM}$ & & $26.64 \pm 10.8^{\mathrm{a}}$ \\
LipoicAcid1 $\mathrm{mM}+$ Trehalose & $26.9 \pm 14.7^{\mathrm{a}}$ & \\
$50 \mathrm{mM}$ & & $20.96 \pm 6.4^{\mathrm{a}}$ \\
Cysteamine $2 \mathrm{mM}+$ & $31.86 \pm 10.1^{\mathrm{a}}$ & \\
LipoicAcid1 $1 \mathrm{mM}$ & & $\mathrm{NS}$ \\
\hline $\mathrm{P}$ & $\mathrm{NS}$ & \\
\hline
\end{tabular}

NS: No significant a, b ,c: Different superscripts within the same column demonstrate significant differences. $\left(*_{\mathrm{p}}<0.05\right)$.

\section{REFERENCES}

Aboagla EME, Terada T. Trehaloseenhanced fluidity of the goat sperm membrane and its protection during freezing. Biol Reprod. 2003; 69(4), 12451250.

Aitken RJ, De Iuliis GN, McLachlan RI. Biological and clinical significance of DNA damage in the male germ line. Int J Androl. 2009; 32(1), 46-56.

Aitken RJ, Gordon E, Harkiss D, Twigg JP, Milne P, Jennings $Z$, Irvine DS. Relative impact of oxidative stress on the functional competence and genomic integrity of human spermatozoa. Biol Reprod. 1998; 59(5), 1037-1046.

Aly HA, Lightfoot DA, El-Shemy HA. Modulatory role of lipoic acid on lipopolysaccharide-induced oxidativestress in adult rat Sertoli cells in vitro. Chem. Biol. Interact. 2009; 18223,112-118.

Bailey JL, Blodeau JF, Cormier N. Semen cryopreservation in domestic animals: A damaging and capacitating phenomenon minireview. J Androl. 2000; 21(1), 1-7.

Balaban RS, Nemoto S, Finkel $T$. Mitochondria, Oxidants, and Aging. Cell. 2005; 120, 483-495.

Bansal AK, Bilaspuri GS. Impacts of oxidative stress and antioxidants on semen functions. Vet Med Int. 2011; doi:10.4061/2011/686137.

Bhattacharyya AK, Chakraborty D, Varghese AC, Bhattachar-yya SM, Kundu S, Banerjee A. Cryopreservation andpost-thaw motility, DNA integrity and acrosome status ofpre-freeze prepared human semen frozen in differenttrehalose concentrations. Hum Reprod. 2006; 21(Suppl 1):393.

Biewenga G, Haenen GRMM, Bast A. The pharmacology of antioxidant lipoicacid. Gen Pharmacol. 1997; 29:315-31.

Bucak MN, Tekin N. Protective effect of taurine, glutathione and trehalose on the liquid storage of ram semen. Small Rumin Ress. 2007; 73(1), 103-108.

Bucak MN, Tuncer PB, Sarıözkan S, Akalın PP, Çoyan K, Başpınar N, Özkalp B, Effects of hypotaurine, cysteamine and aminoacids solution on post-thaw microscopic and oxidative stress parameters of Angora goat semen. Research in Veterinary Science. 2009; 87, 468-472

Bucak MN, Tuncer PB, Sarıözkan S, Başpınar N, Taşpınar M, Çoyan K, Bilgili A, Akalın PP, Büyükleblebici S, Aydos S, Ilgaz S, Sunguroğlu A, Öztuna D, Effects of antioxidants on 
post-thawed bovine sperm and oxidative stress parameters: antioxidants protect DNA integrity against cryodamage. Cryobiology. 2010; 61(3), 248-253.

Chhillar S, Singh VK, Kumar R, Atreja SK.Effects of Taurine or Trehalose supplementation on functional competence of cryopreserved Karan Fries semen. Anim Reprod Sci. 2012; 135(1), 1-7.

Cirit Ü, Bağış H, Demir K, Agca C, Pabuccuoğlu S, Varışlı Ö, CliffordRathertf C, Agca Y. Comparison of cryoprotective effects of iodixanol, trehalose and cysteamine on ram semen. Anim Reprod Sci. 2013; 139(1), 38-44.

Crowe JH, Crowe LM, Carpenter JF, Wistrom CA. Stabilization of dry phospholipid bilayers and proteins by sugars. Biochem J. 1987; 242(1), 1.

De Lamirande E, Jiang H, Zini A, Kodama H, Gagnon C. Reactive oxygen species and sperm physiology. Rev Repord. 1997; 2, 48-54.

De Matos DG, Gasparrini B, Pasqualini SR, Thompson JG. Effect of glutathione synthesis stimulation during in vitro maturation of ovine oocytes on embryo development and intracellular peroxide content. Theriogenology. 2002; 57: 1443-1451.

Desouky OS, Selim, NS, Elbakrawy EM, Rezk RA. Impact evaluation of alphalipoic acid in gamma-irradiated erythrocytes. Radiat Phys Chem. 2011; 803, 446-452.

El-Beshbishy, H Bahashwan, S Ali HAA, Fakher H. Abrogation of cisplatininduced nephrotoxicity in mice by alpha lipoic acid through ameliorating oxidative stress and enhancing gene expression of antioxidant enzymes. Eur J Pharmacol. 2011; 668, 278-284.

El-Sheshtawy RI, Sisy GA, El-Nattat WS. Effects of different concentrations of sucrose or trehalose on the post-thawing quality of cattle bull semen. Asian Pacific Journal of Reproduction. 2015; 4(1), 2631.

Garde JJ, Del Olmo A, Soler AJ, Espeso G, Gomendio M, Roldan ERS. Effect of egg yolk, cryoprotectant, and various sugars on semen cryopreservation in endangered Cuvier's gazelle (Gazella cuvieri). Anim Reprod Sci. 2008; 108(3), 384-401.

Garner DL, Thomas CA, Joerg HW,
Dejarnette JM, Marshall CE. Fluorometric assessments of mitochondrial function and viability in cryopreserved bovine spermatozoa. Biol Reprod. 1997; 57(6), 1401-1406.

Gasparrini B, Sayoud H, Neglia G, de Matos DG, Donnay I, Zicarelli L. Glutatione synthesis during in vitro maturation of buffalo (Bubalus bubalis) oocytes: effects of cysteamine on embryo development Theriogenology. 2003; 60: 943-952.

Gharagozloo P, Aitken RJ. The role of sperm oxidative stress in male infertility and the significance of oral antioxidant therapy. Hum Reprod. 2011; 26(7), 16281640.

Grupen CG, Nagashima H, Nottle MB. Cysteamine enhances in vitro development of porcine oocytes matured and fertilized in vitro. Biol Reprod. 1995; 53: 173-178.

Gutiérrez-Pérez O, Juárez-Mosqueda Mde L, Carvajal SU, Ortega ME. Boar spermatozoa cryopreservation in low glycerol/trehalose enriched freezing media improves cellular integrity. Cryobiology. 2009; 58(3):287-92.

Hu JH, Li QW, Zan LS, Jiang ZL, An JH, Wang LQ, Jia YH. The cryoprotective effect of low-density lipoproteins in extenders on bull spermatozoa following freezing-thawing. Anim Reprod Sci. 2010; 117(1), 11-17.

Khalili B, Farshad A, Zamiri MJ, Rashidi A, Fazeli P. Effects of sucrose and trehalose on the freezability of Markhoz goat spermatozoa. Asian-Aust J Anim Sci. 2009; 22, 1614-1619.

Kito S, Bavister BD. Male pronuclear formation and early embryonic development of hamster oocytes matured in vitro with gonadotrophins, amino acids and cysteamine. J Reprod Fertil. 1997; 110: 35-46.

Medeiros CMO, Forell F, Oliveira ATD, Rodrigues JL. Current status of sperm cryopreservation: why isn't it better? Theriogenology. 2002; 57(1), 327-344.

Merton JS, Knijn HM, Flapper H, Dotinga F, Roelen BA, Vos PL, Mullaart E. Cysteamine supplementation during in vitro maturation of slaughterhouse- and opu-derived bovine oocytes improves embryonic development without affecting cryotolerance, pregnancy rate, and calf characteristics. Theriogenology. 2013; 80: 365-371

Nagy S, Jansen J, Topper EK, Gadella BM. A triple-stain flow cytometric method to 
assess plasma-and acrosome-membrane integrity of cryopreserved bovine sperm immediately after thawing in presence of egg-yolk particles. Biol Reprod. 2003; 68(5), 1828-1835.

Packer L, Witt EH, Tritschler HJ. Alphalipoic as biological antioxidant. Free Rad Biol Med. 1995; 19, 227-250.

Pîndaru LP, Groza IS. Effects of Alpha-Lipoic Acids on Sperm Membrane Integrity during Liquid Storage of Boar Semen. Animal Science and Biotechnologies. 2015; 48 (1); 162-165.

Reddy NSS, Mohanarao GJ, Atreja SK. Effects of adding taurine and trehalose to a tris-based egg yolk extender on buffalo (Bubalus bubalis) sperm quality following cryopreservation. Anim Reprod Sci. 2010; 119(3), 183-190.

Salamon S, Maxwell WMC. Frozen storage of ram semen II. Causes of low fertility after cervical insemination and methods of improvement. Anim Reprod Sci. 1995; 38(1), 1-36.

Sanocka D, Kurpisz M. Reactive oxygen species and sperm cells. Reprod Biol Endocrinol. 2004; 2(12), 1-7.

Schafer S, Holzmann A. The use of transmigration and spermacstain to evaluate epididymal cat spermatozoa. Anim Reprod Sci. 2000; 59: 201-211.

Selvakumar E, Prahalathan C, Sudharsan PT, Varalakshmi P. Chemoprotective effect of lipoic acid against cyclophosphamide-induced changes in the rat sperm. Toxicology. 2006; 217 (1);71-78.

Shen T, Jiang ZL, Li CJ, Hu XC, Li QW. Effect of alpha-lipoic acid on boar spermatozoa quality during freezingthawing. Zygote. 2015; 23;1-7.

Singh VK, Atreja SK, Kumar R, Chhillar S, Singh AK. Assessment of Intracellular $\mathrm{Ca} 2+$, cAMP and 1, 2-Diacylglycerol in Cryopreserved Buffalo (Bubalus bubalis) Spermatozoa on Supplementation of Taurine and Trehalose in the Extender. Reprod Dom Anim. 2012; 47(4), 584-590.

Suzuki JY, Tsuchiya M, Packer L. Lipoic acid and dihydrolipoic acid are novel antioxidants which react with reactive oxygen species. Free Rad Res Commun. 1991; 17, 255-263.

Thibier M, Wagner HG. World statistics for artificial insemination in cattle Livestock Production Science. 2002; 74(2):203212.
Tonieto RA, Goularte KL, Gastal GDA, Schiavon RS, Deschamps JC, Lucia T. Cryoprotectant effect of trehalose and low-density lipoprotein in extenders for frozen ram semen. Small Rumin Ress. 2010; 93(2), 206-209.

Uysal O, Bucak MN, Yavas I, Varisli O. Effect of various antioxidants on the quality of frozen-thawed bull semen. J Anim Vet Adv. 2007; 6(2), 1362-1366.

Vishwanath R, Shannon P. Storage of bovine semen in liquid and frozen state. Anim Reprod Sci. 2000: 62(1), 23-53.

Watson PF. Recent developments and concepts in the cryopreservation of spermatozoa and the assessment of their post-thawing function. Reprod Fertil Dev. 1995; 7(4), 871-891.

Woelders $\boldsymbol{H}$. Fundamentals and recent development in cryopreservation of bull and boar semen. Vet Q. 1997; 19(3), 135 138. 